\title{
Vegetation Degradation of Guanshan Grassland Suppresses the Microbial Biomass and Activity of Soil
}

\author{
Yanmei Liu ${ }^{1,2, *(\mathbb{D}, \text { Hangyu Yang }}{ }^{3}$, Zisheng Xing ${ }^{4}$, Yali Zou ${ }^{1}$ and Zheming Cui ${ }^{1}$ \\ 1 School of Biological Engineering and Technology, Tianshui Normal University, Tianshui 741001, China; \\ zoulzu@163.com (Y.Z.); czm113@126.com (Z.C.) \\ 2 Shapotou Desert Research and Experiment Station, Northwest Institute of Eco-Environment and Resources, \\ Chinese Academy of Sciences, Lanzhou 730000, China \\ 3 Gansu Forestry Technological College, Tianshui 741020, China; yhy-780601@163.com \\ 4 Portage La Prairie Site of Brandon Research and Development Centre, Agriculture and Agri-Food Canada, \\ Brandon, MB R7C 1A1, Canada; zisheng.xing@canada.ca \\ * Correspondence: lym-781118@163.com
}

Citation: Liu, Y.; Yang, H.; Xing, Z.; Zou, Y.; Cui, Z. Vegetation Degradation of Guanshan Grassland Suppresses the Microbial Biomass and Activity of Soil. Land 2021, 10, 203. https://doi.org/10.3390/ land 10020203

Academic Editor: Richard Cruse

Received: 19 January 2021

Accepted: 12 February 2021

Published: 17 February 2021

Publisher's Note: MDPI stays neutral with regard to jurisdictional claims in published maps and institutional affiliations.

Copyright: (c) 2021 by the authors. Licensee MDPI, Basel, Switzerland. This article is an open access article distributed under the terms and conditions of the Creative Commons Attribution (CC BY) license (https:// creativecommons.org/licenses/by/ $4.0 /)$.

\begin{abstract}
Changes in vegetation influence the function of grassland ecosystems. A degradation of the vegetation type has been found from high to low altitudes in Guanshan grassland in the order of forest grassland (FG) < shrub grassland (SG) < herb grassland (HG). However, there is poor information regarding the effect of vegetation degradation on soil microbes in Guanshan grassland. Therefore, our study evaluated the impact of vegetation degradation on the microbial parameters of soil, as well as the mechanisms responsible for these variations. Soils were sampled from 0 to $30 \mathrm{~cm}$ under the FG, SG, and HG in Guanshan grassland for determining the microbial biomass, enzymatic activities, basal respiration (BR), and metabolic quotient $\left(q \mathrm{CO}_{2}\right)$ in April and July 2017. The results showed that vegetation types are important factors that obviously influence the above-mentioned soil microbial properties. The FG and SG had significantly higher soil microbial biomass, enzymatic activities, and BR than those of the HG, but markedly lower $q \mathrm{CO}_{2}(p<0.05)$. Soil $\mathrm{pH}$, available nitrogen (AN), organic carbon (SOC), total phosphorus (TP), available P (AP), and total N (TN) were key factors in the decline in the soil microbial biomass and microbial activities of the degraded vegetation. Moreover, slope aspects also affected the soil microbial properties, with the east slope having higher soil microbial biomass, enzymatic activities, and BR and lower $q \mathrm{CO}_{2}$ than the west slope. Conclusively, vegetation degradation has led to a decline in the soil microbial biomass and microbial activities, indicating the degradation of the Guanshan grassland ecosystem.
\end{abstract}

Keywords: vegetation degradation; soil microbial biomass; soil enzymatic activities; $\mathrm{BR} ; q \mathrm{CO}_{2}$; Guanshan

\section{Introduction}

As the largest terrestrial ecosystem of the Earth, grasslands play a critical part in food production and ecological functioning [1]. However, grassland degradation, a primary contributor to land degradation, is becoming a serious global issue [2]. Approximately $20 \%-35 \%$ of the grasslands across the world [3] and $62 \%$ of the northern Chinese grasslands have suffered different degrees of degradation for several decades [4], caused by natural and anthropogenic factors. Guanshan grassland, a major component of pasture dominated by alpine meadows in northwest China, faces similar challenges [5]. Due to the humid and cool climate, the Guanshan area has historically been covered with dense forests. However, with the increase in the intensity of human activities, especially during the various large-scale reclamations in the Qin (776-772 B.C.), Han (133-71 B.C.), and Tang (650-775 A.D.) Dynasties of China, many forests were cut down and the valleys evolved into grasslands with a high vegetation coverage [6]. In recent years, in some areas of Guanshan where human activities are less important, forest vegetation has been naturally 
restored and has formed natural secondary forests with mixed trees and shrubs, while grassland vegetation continues to degrade, mainly due to human activities from tourism development in other areas [5,6]. Vegetation degradation of Guanshan grassland includes reductions in coverage, species composition, above-ground vegetation biomass, and plant productivity [7]. In addition, these changes of above-ground vegetation further lead to a loss of soil organic carbon (SOC) and nutrients (e.g., total nitrogen (TN), total phosphorus $(\mathrm{TP})$, available $\mathrm{P}(\mathrm{AP})$, and inorganic $\mathrm{N})$, moisture loss [2], weaker soil aggregate stability, high soil erosion, and drastic changes in soil temperature [3,8].

Soil microbes play a vital role in soil quality through the decomposition and mineralization of organic matter in soil and the transformation of nutrients [9]. Soil microbial biomass, indicating the amount of soil microbials, is a major labile pool of nutrients and has a short turnover time of less than one year [10]. Soil enzymes mainly generated by microbes and plants are proteins that allow the energy flow and nutrient circulation of soil by catalyzing biochemical reactions in cells [11]. Soil enzymatic activities and basal respiration (BR) are characterized as soil microbial activity. The metabolic quotient $\left(q \mathrm{CO}_{2}\right)$ explores the inefficient microbial biomass, indicating that a high proportion of soil $\mathrm{C}$ is lost by the released $\mathrm{CO}_{2}$ instead of being utilized for plants [12]. Thus, soil microbial biomass, enzymatic activities, $\mathrm{BR}$, and $q \mathrm{CO}_{2}$ can be used as rapid indicators of above-ground vegetation variations and below-ground soil processes $[13,14]$. In recent decades, the relationship between above-ground vegetation degradation and soil microbial parameters has attracted global attention. For instance, some studies have reported that vegetation degradation can impact soil microbial communities [13], microbial biomass [3], enzymatic activities [15], $\mathrm{BR}$ [16], and $q \mathrm{CO}_{2}$ [17]. Furthermore, a linear relationship between vegetation succession and the microbial diversity, microbial biomass, and microbial activity of soil has been observed in a karst ecosystem [15,17]. Although the effects of degraded vegetation on soil microbial properties have been reported in many areas [13,15-17], the variations and the potential responsible mechanisms of below-ground soil microbes in response to upper vegetation degradation in Guanshan grassland are undocumented, and this is critically needed for successful protection of this grassland ecosystem.

To successfully protect Guanshan grassland from degradation, we need in-depth knowledge on the impact of the current vegetation degradation on the soil processes in the grassland ecosystem in terms of soil physicochemical properties, microbial biomass and activities, and the relationships between soil microbes and physicochemical properties, along with vegetation degradation. Therefore, the goals of this research were to (i) determine the variations in soil physicochemical properties and microbial parameters following the degradation of vegetation and (ii) explore the potential mechanisms of the degradation in the vegetation and soil processes in Guanshan grassland.

\section{Material and Methods}

\subsection{Study Areas}

The sampling sites were in Guanshan grassland, located in the southwest of Long County, Shanxi, at the southern end of the Guanshan Mountains, northwest China $\left(34^{\circ} 43^{\prime} \mathrm{N}\right.$, $\left.106^{\circ} 34^{\prime} \mathrm{E}\right)$. Although the studied region lies in the warm temperate zone with a continental monsoon climate district, it is an alpine mountain climate with short summers and long winters. The average annual temperature is $5.4^{\circ} \mathrm{C}$, with a maximum temperature of $17^{\circ} \mathrm{C}$ in July and a minimum temperature of $-10^{\circ} \mathrm{C}$ in January [5]. The climate is humid, with annual precipitation averaging around $650-700 \mathrm{~mm}$, and the mean annual evaporation is low, with approximately $1318.8 \mathrm{~mm}$ because of the relatively low temperature $[5,18]$. The area includes natural grass on 23,000 ha with an alpine meadow as the main vegetation type, and natural forest on 69,000 ha with trees and shrubs as the main vegetation types. The terrain of the area is U-shaped with a valley sandwiched between two mountains: east and west. The upper soil is classified as huang soil (yellow soil) only within $1 \mathrm{~m}$, whereas the deeper soil is stony. A gradient of vegetation degradation has been determined from high to low altitudes in both the west (relatively flat slope of $25-35^{\circ}$ ) and east (steep slope 
of $40-50^{\circ}$ ) mountains in Guanshan grassland. Detailed descriptions of the topography, vegetation, and soil of the forest grassland (FG), shrub grassland (SG), and herb grassland (HG) of Guanshan grassland are given in Table 1.

Table 1. The information of topography, vegetation, and soil in the study sites of Guanshan grassland.

\begin{tabular}{|c|c|c|c|c|c|}
\hline Vegetation Types & Site & Altitude (m) & Dominant Species [5] & $\begin{array}{l}\text { Vegetation } \\
\text { Coverage }\end{array}$ & Soil Types \\
\hline \multirow[t]{2}{*}{$\begin{array}{l}\text { Forestgrass } \\
\text { land (FG) }\end{array}$} & \multirow[t]{2}{*}{ Mountain top } & \multirow[t]{2}{*}{$2350-2400$} & $\begin{array}{l}\text { Trees and shrubs, including Pinus } \\
\text { tabuliformis Carr., Salix } \\
\text { pseudotangii C. Wang et C. Y. Yu, } \\
\text { Hippophae rhamnoides Linn., } \\
\text { Populus tomentosa Carr., } \\
\text { Rhododendron simsii Planch., etc. }\end{array}$ & $60 \%-70 \%$ & \multirow[t]{2}{*}{ Yellow soil } \\
\hline & & & $\begin{array}{l}\text { Dwarf grasses, including Festuca } \\
\text { rubra Linn., Carex lehmanii Drej., } \\
\text { Medicago lupulina Linn., etc. }\end{array}$ & $20 \%-30 \%$ & \\
\hline \multirow{2}{*}{$\begin{array}{l}\text { Shrub grassland } \\
\text { (SG) }\end{array}$} & \multirow{2}{*}{ Mountain middle } & \multirow{2}{*}{$2100-2200$} & $\begin{array}{l}\text { Trees and shrubs, including } S \text {. } \\
\text { pseudotangii C. Wang et C. Y. Yu, } \\
\text { Betula albo-sinensis Burk., Populus } \\
\text { davidiana Dode, etc. }\end{array}$ & $30 \%-40 \%$ & \multirow{2}{*}{ Yellow soil } \\
\hline & & & $\begin{array}{c}\text { Dwarf grasses with coverage, } \\
\text { including F. rubra Linn., } \\
\text { Leontopodium leontopodiodes } \\
\text { (Willd.) Beauv., C. lehmanii Drej., } \\
\text { Elymus daburicus Turcz., etc. }\end{array}$ & $40 \%-50 \%$ & \\
\hline $\begin{array}{l}\text { Herb grassland } \\
\text { (HG) }\end{array}$ & Mountain base & $2050-2100$ & $\begin{array}{c}\text { Trees and shrubs } \\
\text { Dwarf grass, including Duchesnea } \\
\text { indica (Andr.) Fock., Ranunculus } \\
\text { japonicas Thunb., C. lehmanii Drej., } \\
\text { Cyperus sp., Anemone rivularis } \\
\text { Buch.-Ham., etc. }\end{array}$ & $\begin{array}{l}<1 \% \\
70 \%\end{array}$ & Yellow soil \\
\hline
\end{tabular}

\subsection{Experimental Design and Soil Sampling Collection}

To systematically monitor the impact of vegetation degradation in Guanshan grassland on the microbial biomass and activity of soil, the east slope of the west mountain and the west slope of the east mountain were chosen as experimental locations with similar environmental conditions and similar disturbance from tourism activities to cross-check the credibility of our results. We randomly selected five $2 \times 2 \mathrm{~m}$ plots of each vegetation type (FG, SG, and HG) for both the east and west slopes, resulting in a total of 30 plots. Within each plot, soil samples were collected from depths of 0-10, 10-20, and 20-30 cm by using a $10 \mathrm{~cm}$ inner diameter soil auger on 5 April and 5 July 2017. Each soil sample at a given depth in the FG, SG, and HG sites was composed of five duplicate samples taken at the same soil depth from five plots with the same aspect, and mixed completely as a soil sample. Each mixed soil sample was sieved using a $2 \mathrm{~mm}$ mesh and split into two parts. The first part was immediately kept at $4{ }^{\circ} \mathrm{C}$ for determining the soil microbial biomass, enzymatic activities, $\mathrm{BR}$, and $q \mathrm{CO}_{2}$, and the other part was air-dried for analyzing the soil physicochemical properties. A detailed schematic diagram of the experimental design is shown in Figure 1. 


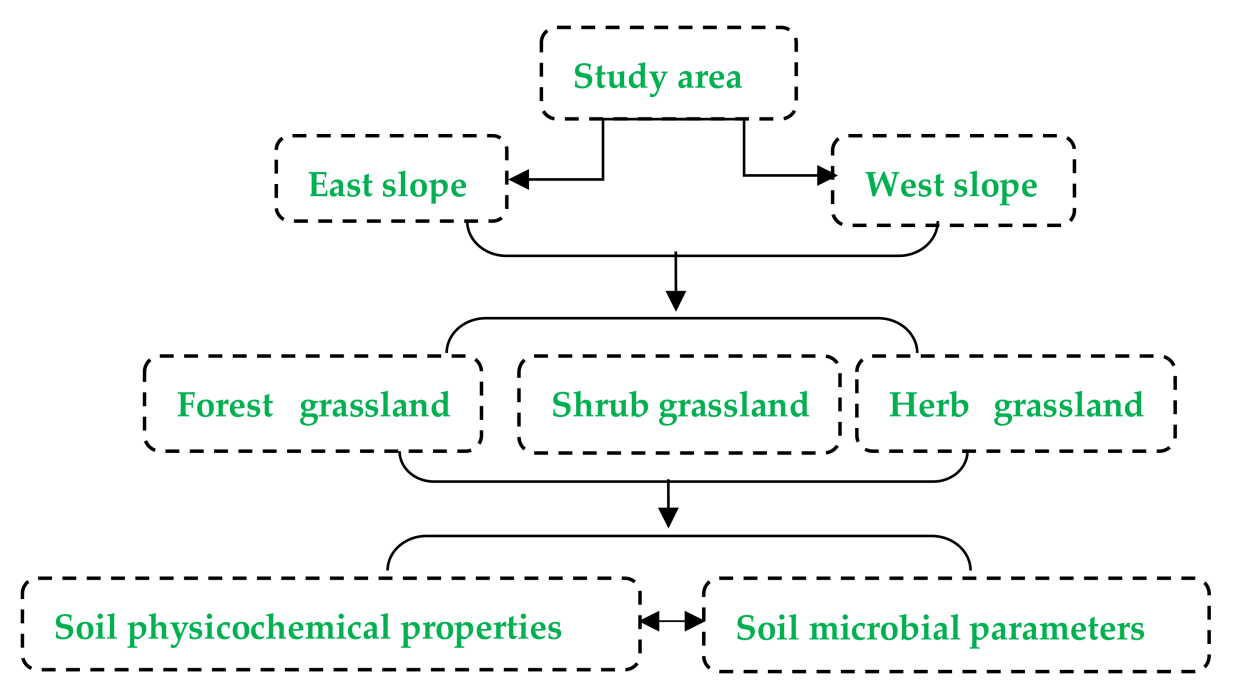

Figure 1. A schematic diagram of the experimental design.

\subsection{Analyses of the Soil Physicochemical Properties}

Soil moisture (SM) was determined by oven-drying fresh soils at $105{ }^{\circ} \mathrm{C}$. The soil $\mathrm{pH}$ was measured using a $\mathrm{pH}$ glass electrode in a 1:5 (w/v) soil-to-water ratio. The SOC and TN contents were analyzed by the methods of potassium dichromate oxidation titration [19] and Kjeldahl digestion-the distillation azotometry following $98 \% \mathrm{H}_{2} \mathrm{SO}_{4}$ extraction [20], respectively. The available $\mathrm{N}(\mathrm{AN})$ was measured using the method of alkaline diffusion [19]. TP and AP were measured colorimetrically by the molybdenum blue method at $700 \mathrm{~nm}$ after extraction using a $\mathrm{H}_{2} \mathrm{SO}_{4}-\mathrm{HClO}_{4}$ and $\mathrm{NaHCO}_{3}$ solution, respectively [21]. Total potassium (TK) and available $\mathrm{K}(\mathrm{AK})$ were determined by a flame photometer after $\mathrm{NaOH}$ fusion and $\mathrm{NH}_{4} \mathrm{OAc}$ extraction, respectively [22].

\subsection{Analyses of the Soil Microbial Biomass}

Soil microbial biomass C (Cmic), N (Nmic), and P (Pmic) were determined by the method of chloroform fumigation-extraction following Brookes et al. [23,24] and Vance et al. [25]. For the Cmic and Nmic analyses, soil samples were fumigated with ethanol-free chloroform at room temperature for 1 day (with corresponding nonfumigated controls), and extracted using $0.5 \mathrm{M} \mathrm{K}_{2} \mathrm{SO}_{4}$ (the ratio of soil to solution = 1:4 w/v) by shaking for $30 \mathrm{~min}$ and filtered. The organic $\mathrm{C}$ and total $\mathrm{N}$ in the soil extracts were determined using the methods of potassium dichromate oxidation and Kjeldahl digestion, respectively. For Pmic, soil samples both fumigated with free ethanol-chloroform at $25^{\circ} \mathrm{C}$ for $24 \mathrm{~h}$ and nonfumigated were extracted with $0.5 \mathrm{M} \mathrm{NaHCO}_{3}$ (soil/solution $=1: 20 \mathrm{w} / \mathrm{v}$ ) by shaking for $30 \mathrm{~min}$ and then filtered. The Pmic was determined using the ammonium molybdatestannous chloride method. The $\mathrm{Cmic}$, Nmic, and Pmic were estimated using the following formulas:

$$
\begin{aligned}
C_{\text {mic }} & =\frac{E_{C}}{K_{E C}} \\
N_{\text {mic }} & =\frac{E_{N}}{K_{E N}} \\
P_{\text {mic }} & =\frac{E_{P}}{K_{E P}}
\end{aligned}
$$

where $E_{C}, E_{N}$, and $E_{P}$ are the differences between the $C, N$, and $P$ fumigated and nonfumigated extracts, respectively, and $\mathrm{K}_{\mathrm{EC}}, \mathrm{K}_{\mathrm{EN}}$, and $\mathrm{K}_{\mathrm{EP}}=0.38$ [25], 0.54 [23], and 0.4 [24], respectively. 


\subsection{Analyses of the Soil Microbial Activities}

Soil enzymatic activities, including C cycled (sucrase and cellulase), N cycled (urease and protease), $\mathrm{P}$ cycled (alkaline phosphatase), and two intracellular enzymes (catalase and dehydrogenase), were measured following the methods as described by Liu et al. [26]. In brief, urease activity was measured based on ammonia release following urea as the substrate and expressed as $\mathrm{mg} \mathrm{NH}_{4}^{+}-\mathrm{N} \mathrm{g}^{-1}$ soil $\mathrm{h}^{-1}$. The sucrase and cellulase activities were determined by the production of glucose, following sucrose and carboxymethyl cellulose as decomposed substrates, respectively, and defined as mg glucose $\mathrm{g}^{-1}$ soil $\mathrm{h}^{-1}$ and $\mu \mathrm{g}$ glucose $\mathrm{g}^{-1}$ soil $^{-1}$, respectively. The catalase activity was analyzed by back-titrating the remaining $\mathrm{H}_{2} \mathrm{O}_{2}$ with $0.1 \mathrm{~N} \mathrm{KMnO}_{4}$, following $\mathrm{H}_{2} \mathrm{O}_{2}$ as the substrate, expressed as $\mathrm{mL}$ $\mathrm{KMnO}_{4} \mathrm{~g}^{-1}$ soil $\mathrm{h}^{-1}$. The dehydrogenase activity was analyzed by the released production of 1,2,5-triphenylformazan (TPF), following 2,3,5-triphenyltetrazolium chloride as the decomposed substrate, defined as $\mu \mathrm{g}$ TPF g ${ }^{-1}$ soil h$^{-1}$. The alkaline phosphatase activity was measured through the formed $p$-nitrophenol, following $p$-nitrophenyl phosphate as the decomposed substrate, shown as $\mu \mathrm{g} p$-nitrophenol $\mathrm{g}^{-1}$ soil $^{-1}$. The protease activity was analyzed by tyrosine release from casein as the decomposed substrate, shown as $\mu \mathrm{g}$ tyrosine $\mathrm{g}^{-1}$ soil $^{-1}$. Soil BR, using the alkali absorption method, was analyzed by incubating $50 \mathrm{~g}$ soil samples at $60 \%$ field capacity at $25^{\circ} \mathrm{C}$ in darkness for $24 \mathrm{~h}$, alongside $10 \mathrm{~mL}$ of $0.1 \mathrm{M} \mathrm{NaOH}$. The released $\mathrm{CO}_{2}$ from soil microbes was captured by the alkali and was ascertained by titrating with $0.1 \mathrm{M} \mathrm{HCl}$ after adding $4 \mathrm{~mL}$ of $1 \mathrm{M} \mathrm{BaCl}_{2}$ and $0.2 \mathrm{~mL}$ of phenolphthalein. The $q \mathrm{CO}_{2}$ was calculated by the ratio of soil BR and the Cmic.

\subsection{Statistics Analysis}

The soil physicochemical properties, microbial biomass, enzymatic activities, BR, and $q \mathrm{CO}_{2}$ for FG, SG, and HG were analyzed with the Shapiro-Wilk test to determine the normal distribution, and then Duncan's tests were conducted with a one-factor analysis of variance (ANOVA). A multivariate ANOVA with Tukey's honestly significant difference tests was adopted to test the interactions of the vegetation types, the slope aspect, and the soil depth on the soil microbial biomass, enzymatic activities, $\mathrm{BR}$, and $q \mathrm{CO}_{2}$. All data are shown as means of five replicates \pm standard error (SE). Pearson's correlations were performed to assess the relationships between the soil microbial parameters and the soil depth. Differences were considered significant when $p<0.05$ in all ANOVAs and Pearson's correlations. All data were analyzed with SPSS 16.0 statistical software. In addition, to explore the relationships between the soil microbial parameters and the physicochemical factors for different vegetation types, a redundancy analysis (RDA) was employed based on the Monte Carlo test using CANOCO 4.5 software.

\section{Results}

\subsection{Changes of the Soil Physicochemical Properties Related to Vegetation Types}

The soil physicochemical properties in the $0-30 \mathrm{~cm}$ soil layers from the east and west slopes of Guanshan grassland varied with the vegetation type. The SOC, TN, AN, TP, AP, TK, and AK were the highest in FG, followed by SG and then HG (Table 2). These soil physicochemical properties were significantly greater in FG and SG than in HG $(p<0.05)$. In contrast, the soil $\mathrm{pH}$ was higher in $\mathrm{HG}$ than in $\mathrm{SG}$, and the soil $\mathrm{pH}$ in $\mathrm{SG}$ was also dramatically higher than in FG (Table 2) $(p<0.05)$.

\subsection{Changes in the Soil Microbial Biomass Related to Vegetation Types}

Vegetation types were significantly associated with the soil microbial biomass parameters, such as Cmic, Nmic, and Pmic, in the $0-30 \mathrm{~cm}$ soil layers from the east and west slopes (Figure 2). In July, the Cmic, Nmic, and Pmic in FG were obviously greater by $84.7 \%, 53.7 \%$, and $27.1 \%$ from the east slope soil and by $48.6 \%, 58.3 \%$, and $28.2 \%$ from the west slope soil, respectively, than in HG at soil depths of $0-10,10-20$, and $20-30 \mathrm{~cm}$ $(p<0.05)$; correspondingly, the Cmic, Nmic, and Pmic in SG were significantly higher by $56.6 \%, 37.3 \%$, and $44.3 \%$ from the east slope soil and by $43.4 \%, 34.7 \%$, and $37.6 \%$ from the 
west slope soil relative to HG (Figure 2) $(p<0.05)$. In April, the Cmic, Nmic, and Pmic in FG were higher than in SG, and in SG were greater than in HG (Figure 3). In both April and July, the Cmic, Nmic, and Pmic in FG and SG were significantly higher than those in HG from the east and west slope soils (Figures 2 and 3) $(p<0.05)$.

Table 2. The physicochemical properties of the 0-30 cm soil layers under the different types of vegetation in Guanshan grassland.

\begin{tabular}{|c|c|c|c|c|c|c|c|c|c|c|}
\hline $\begin{array}{l}\text { Slope } \\
\text { Aspect }\end{array}$ & $\begin{array}{l}\text { Vegetation } \\
\text { Types }\end{array}$ & $\underset{\left(\mathrm{g} \mathrm{kg}^{-1}\right)}{\mathrm{SOC}}$ & $\begin{array}{c}\mathrm{TN} \\
\left(\mathrm{g} \mathrm{kg}^{-1}\right)\end{array}$ & $\begin{array}{c}\mathrm{AN} \\
\left(\mathrm{mg} \mathrm{kg}^{-1}\right)\end{array}$ & $\begin{array}{c}\mathrm{TP} \\
\left(\mathrm{g} \mathrm{kg}^{-1}\right)\end{array}$ & $\begin{array}{c}\mathrm{AP} \\
\left(\mathrm{mg} \mathrm{kg}^{-1}\right)\end{array}$ & $\begin{array}{c}\text { TK } \\
\left(\mathrm{g} \mathrm{kg}^{-1}\right)\end{array}$ & $\underset{\left(\mathrm{mg} \mathrm{kg}^{-1}\right)}{\mathrm{AK}}$ & $\mathrm{pH}$ & SM \\
\hline East & $\begin{array}{l}\text { Forest grassland } \\
\text { (FG) }\end{array}$ & $\begin{array}{c}81.48 \pm \\
1.29 \mathrm{a}\end{array}$ & $\begin{array}{l}3.83 \pm \\
0.02 \mathrm{a}\end{array}$ & $\begin{array}{c}236.37 \pm \\
4.72 \mathrm{a}\end{array}$ & $\begin{array}{c}36.09 \pm \\
0.27 \mathrm{a}\end{array}$ & $\begin{array}{c}18.33 \pm \\
0.42 \mathrm{a}\end{array}$ & $\begin{array}{l}9.90 \pm \\
0.08 \mathrm{a}\end{array}$ & $\begin{array}{c}173.44 \pm \\
1.66 \mathrm{a}\end{array}$ & $\begin{array}{l}6.43 \pm \\
0.01 \mathrm{c}\end{array}$ & $\begin{array}{l}0.25 \pm \\
0.01 \mathrm{a}\end{array}$ \\
\hline \multirow[t]{3}{*}{ Slope } & Shrub grassland & $77.19 \pm$ & $3.30 \pm$ & $200.20 \pm$ & $25.13 \pm$ & $9.79 \pm$ & $8.47 \pm$ & $163.33 \pm$ & $6.52 \pm$ & $0.22 \pm$ \\
\hline & $\begin{array}{l}\text { (SG) } \\
\text { Herb grassland }\end{array}$ & $\begin{array}{l}0.63 \mathrm{~b} \\
71.84+\end{array}$ & $\begin{array}{l}0.05 \mathrm{~b} \\
2.24 \mathrm{t}\end{array}$ & $\begin{array}{c}2.43 \mathrm{~b} \\
169.87 \pm\end{array}$ & $\begin{array}{l}0.32 \mathrm{~b} \\
21.75+\end{array}$ & $\begin{array}{l}0.18 \mathrm{~b} \\
4.08+\end{array}$ & $\begin{array}{l}0.04 \mathrm{~b} \\
8.40+\end{array}$ & $\begin{array}{c}1.33 \mathrm{~b} \\
132.89 \pm\end{array}$ & $\begin{array}{l}0.01 \mathrm{~b} \\
6.61+\end{array}$ & $\begin{array}{l}0.01 \mathrm{ab} \\
0.20 \pm\end{array}$ \\
\hline & (HG) & $0.99 \mathrm{c}$ & $\begin{array}{l}2.24 \perp \\
0.03 c\end{array}$ & $2.33 \mathrm{c}$ & $0.30 \mathrm{c}$ & $\begin{array}{l}.00 \mathrm{C} \\
0.08 \mathrm{c}\end{array}$ & $0.08 \mathrm{~b}$ & $1.24 \mathrm{c}$ & $\begin{array}{l}0.01 \perp \\
0.02 \mathrm{a}\end{array}$ & $0.01 \mathrm{~b}$ \\
\hline West & Forest grassland & $61.60 \pm$ & $2.75 \pm$ & $204.87 \pm$ & $25.27 \pm$ & $17.21 \pm$ & $8.38 \pm$ & $139.44 \pm$ & $6.47 \pm$ & $0.24 \pm$ \\
\hline \multirow[t]{4}{*}{ Slope } & Shrub grassland & $58.55 \pm$ & $2.04 \pm$ & $194.14 \pm$ & $19.49 \pm$ & $8.30 \pm$ & $8.06 \pm$ & $146.78 \pm$ & $6.54 \pm$ & $0.23 \pm$ \\
\hline & (SG) & $2.73 \mathrm{a}$ & $0.04 \mathrm{~b}$ & $2.70 \mathrm{a}$ & $0.14 \mathrm{~b}$ & $0.10 \mathrm{~b}$ & $0.04 \mathrm{~b}$ & $3.82 \mathrm{a}$ & $0.02 \mathrm{~b}$ & $0.01 \mathrm{a}$ \\
\hline & Herb grassland & $41.73 \pm$ & $1.60 \pm$ & $164.42 \pm$ & $16.61 \pm$ & $3.95 \pm$ & $7.96 \pm$ & $117.22 \pm$ & $6.68 \pm$ & $0.23 \pm$ \\
\hline & (HG) & $0.70 \mathrm{~b}$ & $0.03 \mathrm{c}$ & $3.04 \mathrm{~b}$ & $1.04 \mathrm{c}$ & $0.14 \mathrm{c}$ & $0.02 \mathrm{~b}$ & $3.19 \mathrm{~b}$ & $0.02 \mathrm{a}$ & $0.00 \mathrm{a}$ \\
\hline
\end{tabular}

Notes: Data are presented as mean \pm standard error (SE) $(n=5)$. Significant differences are marked with different lower letters $(\mathrm{a}, \mathrm{b}$, and $\mathrm{c})$ at $p<0.05$. SOC, soil organic carbon; TN, total nitrogen; AN, available nitrogen; TP, total phosphorus; AP, available phosphorus; TK, total potassium; AK, available potassium; SM, soil moisture.
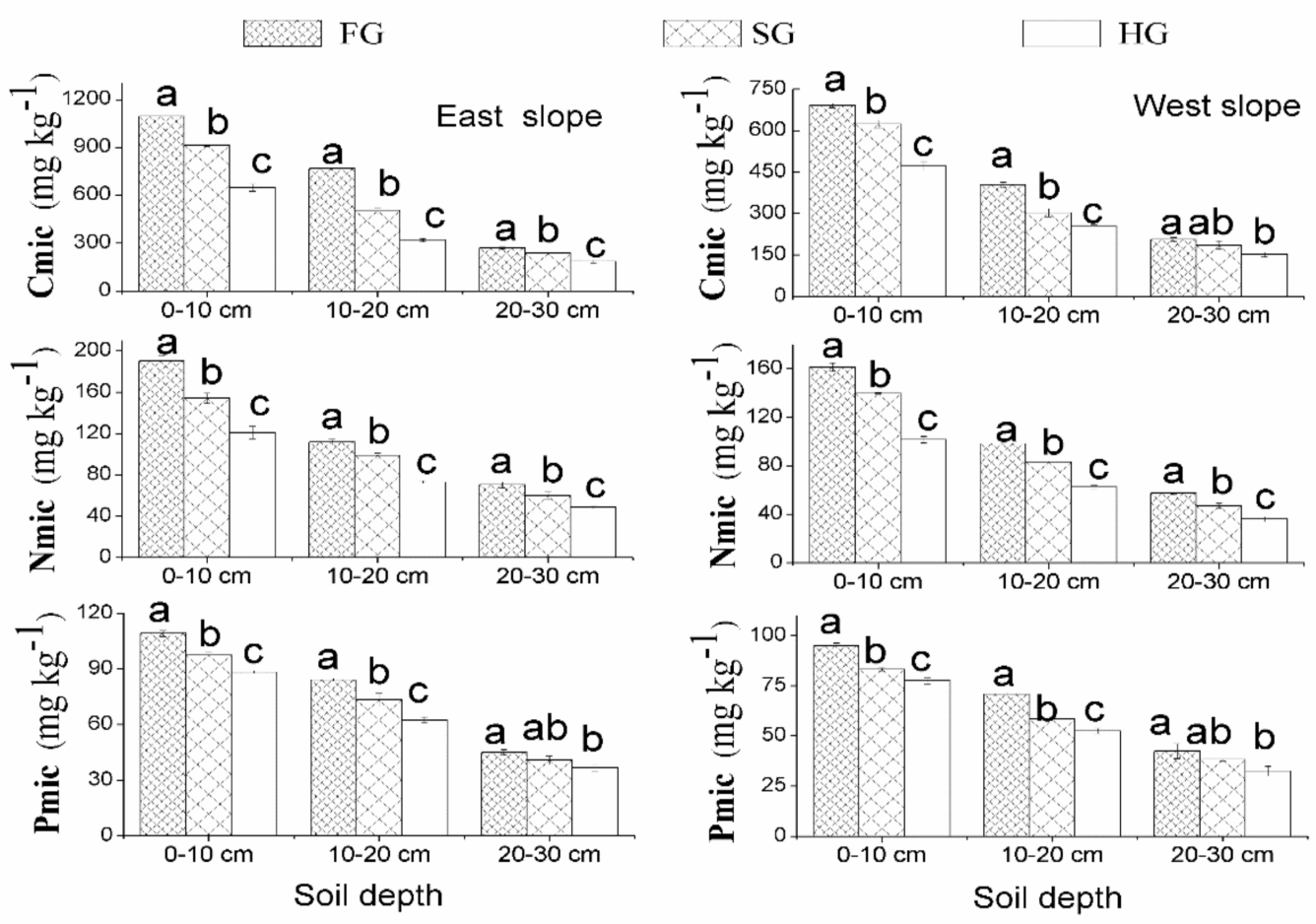

Figure 2. The microbial biomass carbon ( $\mathrm{Cmic}$ ), nitrogen (Nmic), and phosphorus (Pmic) related to vegetation types in July 2017 from the east and west slopes of Guanshan grassland (mean \pm SE; $n=5$ ). Significant differences are marked with different lower letters $(\mathrm{a}, \mathrm{b}$, and $\mathrm{c})$ at $p<0.05$. 


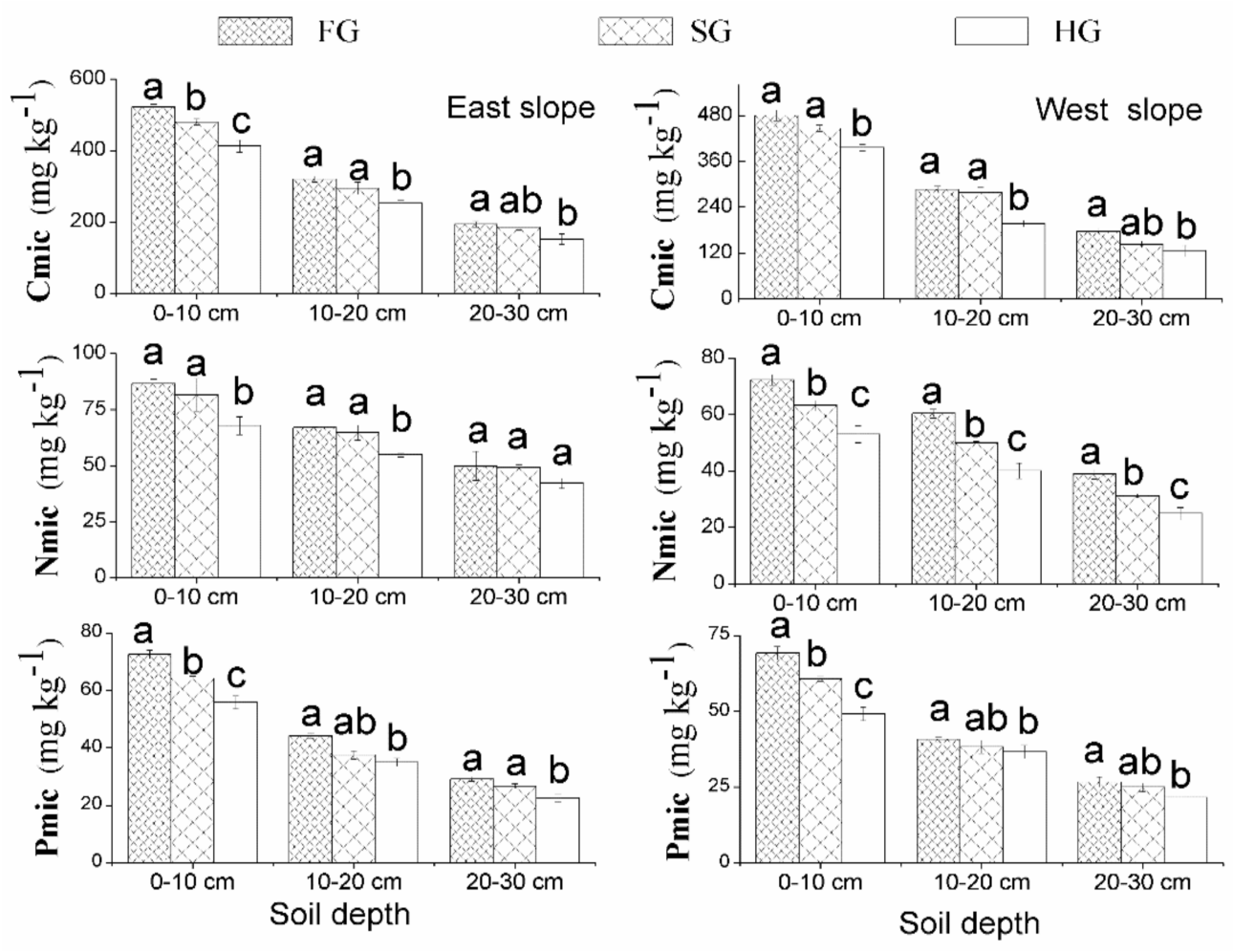

Figure 3. The microbial biomass carbon (Cmic), nitrogen (Nmic), and phosphorus (Pmic) related to vegetation types in April 2017 from east and west slopes of Guanshan grassland (mean $\pm S E ; n=5$ ). Significant differences are marked with different lower letters $(\mathrm{a}, \mathrm{b}$, and $\mathrm{c})$ at $p<0.05$.

The soil microbial biomass also significantly differed with slope aspect, soil depth, and the interactions between vegetation types $\times$ slope aspect and vegetation types $\times$ soil depth ( $p<0.05$; Table 3). The east slope had obviously greater Cmic, Nmic, and Pmic than the west slope (i.e., the Cmic, Nmic, and Pmic for the east slope were significantly greater than for the west slope by 33.4\%, 15.2\%, and 13.6\% in July, respectively). The Cmic, Nmic, and Pmic were highly and significantly negatively correlated (all $p<0.05$ ) with soil depth (east slope: $r=-0.998,-0.988$, and -0.997 , respectively; west slope: $r=-0.982,-0.992$, and -1.0 , respectively; $p<0.05$ ). Similarly, the interactions between vegetation types $\times$ slope aspect and vegetation types $\times$ soil depth for $\mathrm{Cmic}, \mathrm{Nmic}$, and Pmic indicated that the impact of vegetation types on the soil microbial biomass differed with slope aspect and soil depth.

Table 3. Multivariate analysis of variance (ANOVA) for the microbial biomass, basal respiration (BR), and metabolic quotient $\left(q \mathrm{CO}_{2}\right)$ of soil related to different types of vegetation in Guanshan grassland.

\begin{tabular}{|c|c|c|c|c|c|c|}
\hline \multirow{2}{*}{ Source of Variation } & \multirow{2}{*}{ df } & \multicolumn{5}{|c|}{ Mean Squares } \\
\hline & & Cmic & Nmic & Pmic & BR & $q \mathrm{CO}_{2}$ \\
\hline Vegetation types & 2 & $1,300,408.50^{* * *}$ & $38,366.48^{* * *}$ & $12,414.70 * * *$ & $6956.16^{* * *}$ & $0.07^{* * *}$ \\
\hline Slope aspect & 1 & $454,039.52 * * *$ & $3332.16^{* * *}$ & $1251.85^{* * *}$ & $4933.85^{* * *}$ & $0.01 \mathrm{~ns}$ \\
\hline Soil depth & 2 & $245,950.88^{* * *}$ & $7663.83 * * *$ & $1175.46^{* * *}$ & $95,075.23 * * *$ & $0.67^{* * *}$ \\
\hline Vegetation types $\times$ slope aspect & 2 & $68,045.06^{* * *}$ & $99.40 *$ & $145.95^{* * *}$ & $916.38^{* * *}$ & $0.00 *$ \\
\hline Vegetation types $\times$ soil depth & 4 & $33,478.86^{* * *}$ & $711.99^{* * *}$ & $58.10 * *$ & $505.65^{* * *}$ & $0.01 * *$ \\
\hline Slope aspect $\times$ soil depth & 2 & $38,048.38^{* * *}$ & $27.46 \mathrm{~ns}$ & $6.02 \mathrm{~ns}$ & $179.20 *$ & $0.00 \mathrm{~ns}$ \\
\hline $\begin{array}{l}\text { Vegetation types } \times \text { slope aspect } \\
\times \text { soil depth }\end{array}$ & 4 & $7160.85^{* * *}$ & $31.12 \mathrm{~ns}$ & $5.32 \mathrm{~ns}$ & $99.80 \mathrm{~ns}$ & $0.01 *$ \\
\hline
\end{tabular}




\subsection{Changes in the Soil Enzymatic Activities, $B R$, and $q \mathrm{CO}_{2}$ Related to Vegetation Types}

The vegetation types were associated with the enzymatic activities, $\mathrm{BR}$, and $q \mathrm{CO}_{2}$ in the $0-30 \mathrm{~cm}$ soil layers from the east and west slopes (Figures 4-7). In July, the soil urease, sucrase, catalase, dehydrogenase, alkaline phosphatase, protease, and cellulase activities and the BR in the 0-30 cm soil layers for FG were much greater than for HG by $113.8 \%, 76.7 \%, 8.6 \%, 112.5 \%, 119.6 \%, 79.4 \%, 60.1 \%$, and $24.1 \%$ from the east slope, respectively, and by $161.7 \%, 79.6 \%, 7.5 \%, 247.1 \%, 39.4 \%, 129.5 \%, 64.0 \%$, and $15.8 \%$ from the west slope $(p<0.05)$, respectively. The urease, sucrase, catalase, dehydrogenase, alkaline phosphatase, protease, and cellulase activities and the BR at soil depths of 0-30 cm for SG were significantly greater than for HG by $47.2 \%, 38.6 \%, 4.4 \%, 53.1 \%, 50.0 \%, 30.6 \%, 21.6 \%$, and $6.0 \%$ from the east slope, respectively, and by $73.8 \%, 40.8 \%, 5.7 \%, 110.7 \%, 14.2 \%, 53.6 \%$, $24.8 \%$, and $6.7 \%$ from the west slope, respectively (Figures 4 and 6$)(p<0.05)$. In contrast, the $q \mathrm{CO}_{2}$ in the $0-30 \mathrm{~cm}$ soil layers for FG was significantly lower by $19.1 \%$ and $11.3 \%$ than for HG from the east and west slopes, respectively (Figure 6) $(p<0.05)$; meanwhile, the $q \mathrm{CO}_{2}$ in SG was obviously lower compared to in $\mathrm{HG}(p<0.05)$ by $6.4 \%$ and $4.3 \%$ from the east and west slopes, respectively (Figure 6).

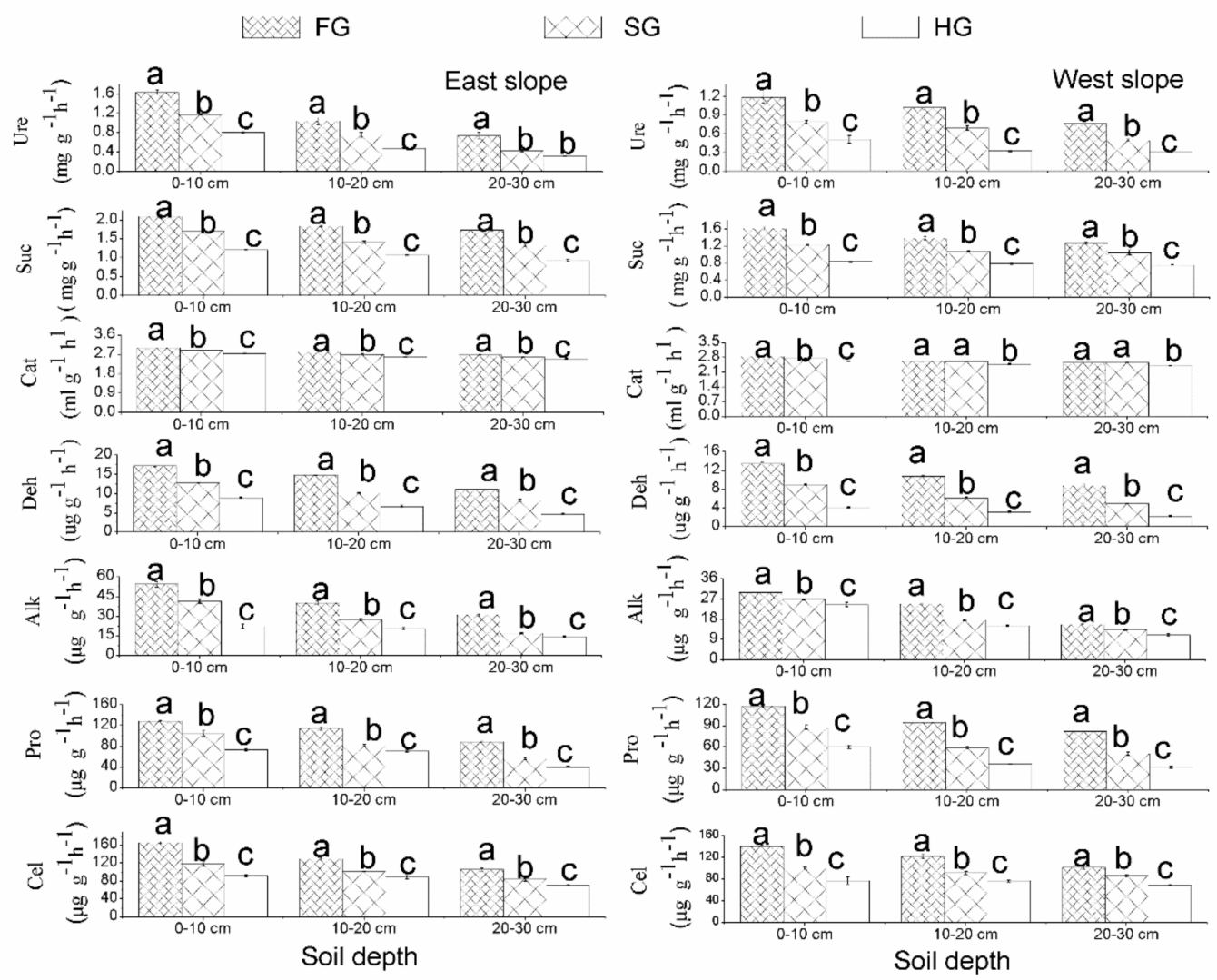

Figure 4. Soil urease (Ure), sucrase (Suc), catalase (Cat), dehydrogenase (Deh), alkaline phosphatase (Alk), protease (Pro), and cellulose (Cel) activities related to vegetation types in July 2017 from the east and west slopes of Guanshan grassland (mean $\pm \mathrm{SE} ; n=5)$. Significant differences are marked with different lower letters $(\mathrm{a}, \mathrm{b}$, and $\mathrm{c})$ at $p<0.05$. 


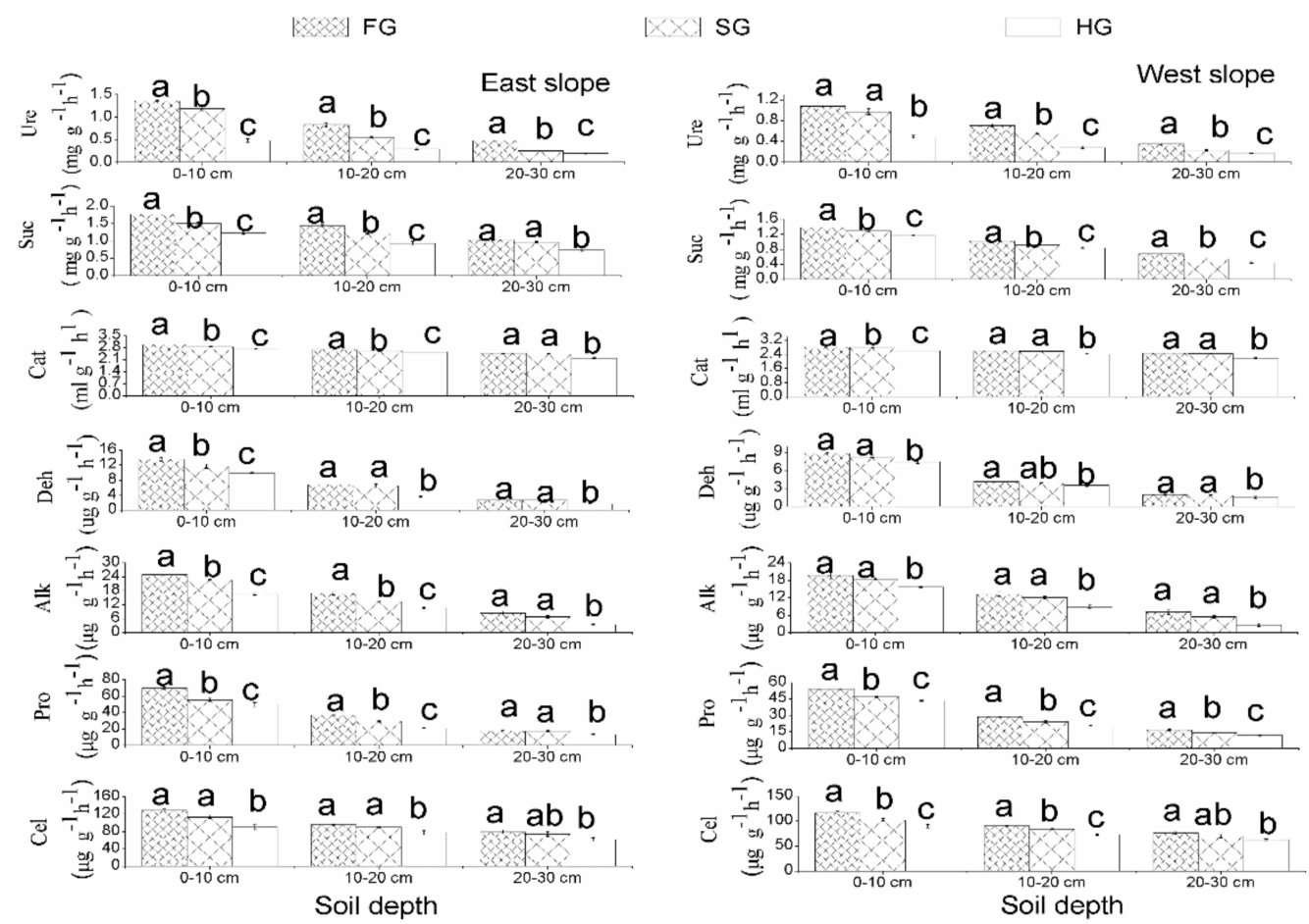

Figure 5. Soil urease (Ure), sucrase (Suc), catalase (Cat), dehydrogenase (Deh), alkaline phosphatase (Alk), protease (Pro), and cellulose (Cel) activities related to vegetation types in April 2017 from the east and west slopes of Guanshan grassland (mean $\pm \mathrm{SE} ; n=5)$. Significant differences are marked with different lower letters $(\mathrm{a}, \mathrm{b}$, and $\mathrm{c})$ at $p<0.05$.

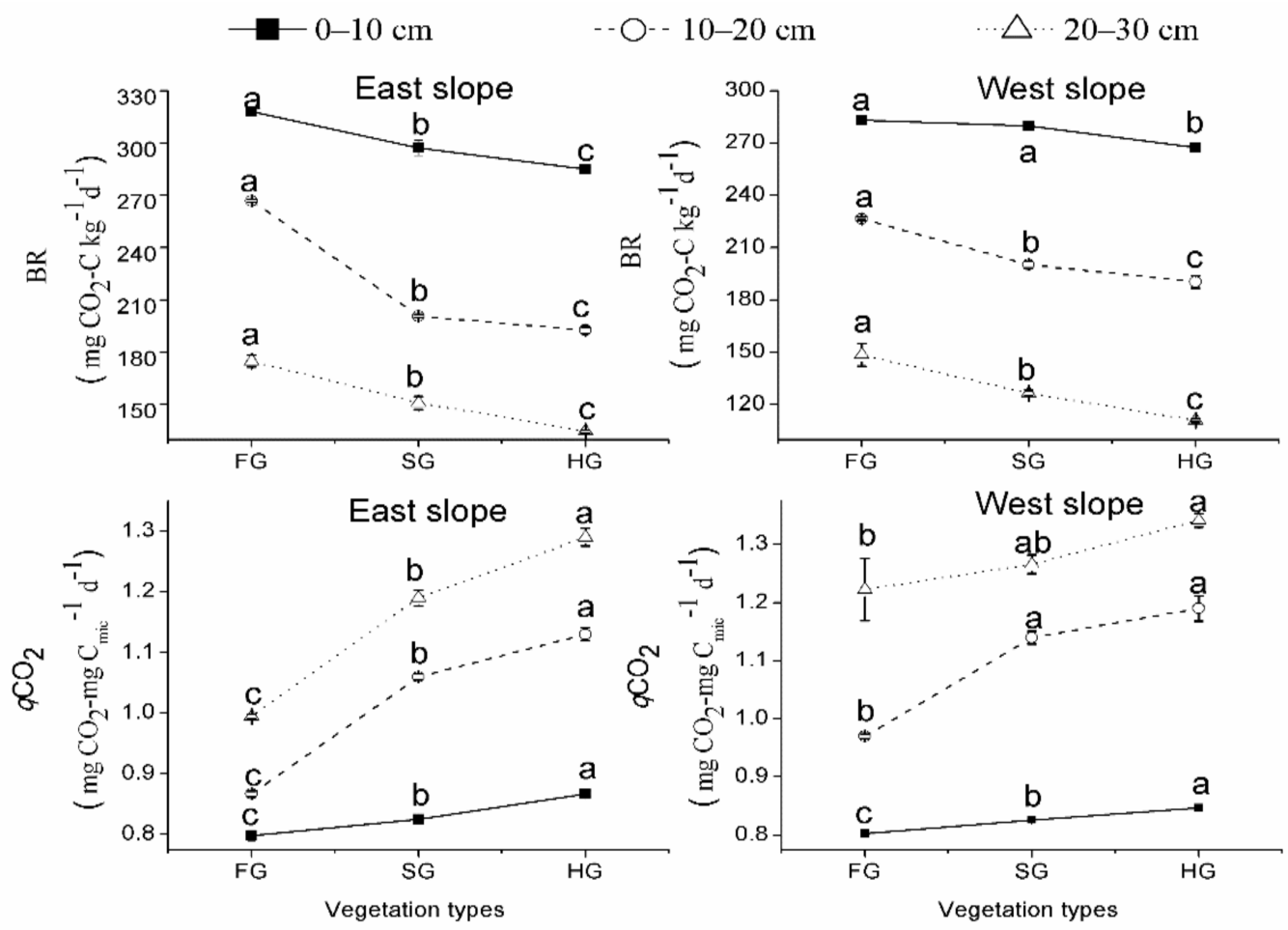

Figure 6. Soil basal respiration (BR) and metabolic quotient $\left(q \mathrm{CO}_{2}\right)$ related to vegetation types in July 2017 from the east and west slopes of Guanshan grassland (mean \pm SE; $n=5$ ). Significant differences are marked with different lower letters $(\mathrm{a}, \mathrm{b}$, and c) at $p<0.05$. 

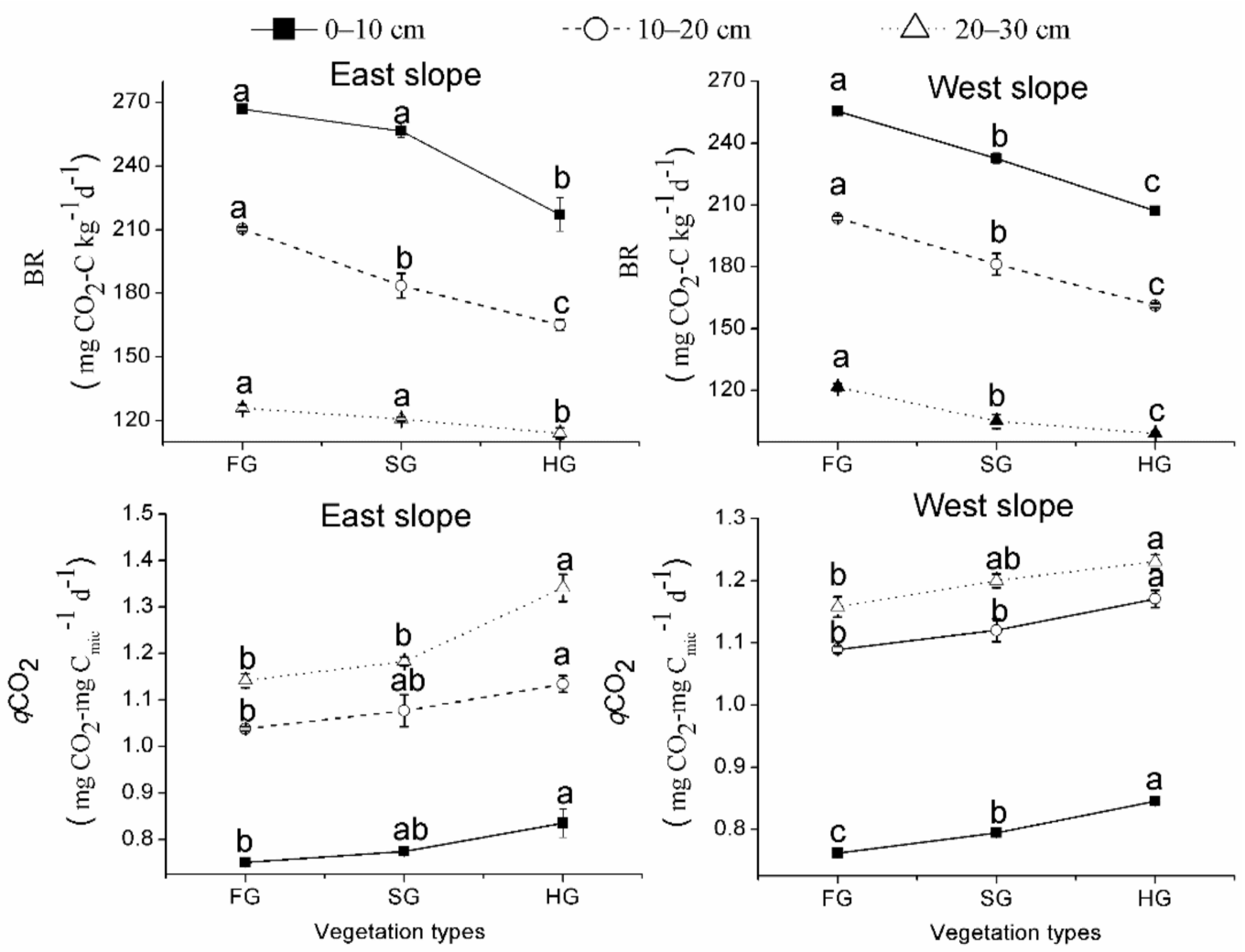

Figure 7. Soil basal respiration (BR) and metabolic quotient $\left(q \mathrm{CO}_{2}\right)$ related to vegetation types in April 2017 from the east and west slopes of Guanshan grassland (mean $\pm \mathrm{SE} ; n=5$ ). Significant differences are marked with different lower letters $(\mathrm{a}, \mathrm{b}$, and $\mathrm{c})$ at $p<0.05$.

In April, FG had the highest soil urease, sucrase, catalase, dehydrogenase, alkaline phosphatase, protease, and cellulase activities and soil BR, followed by SG and then HG, with FG and SG significantly higher than HG (Figures 5 and 7) $(p<0.05)$. However, the $q \mathrm{CO}_{2}$ in FG and SG soil showed an opposite trend to the soil enzymatic activities, and the BR was markedly lower than in HG soil (Figure 7) $(p<0.05)$.

A multivariate ANOVA clearly showed that the enzymatic activities, $B R$, and $q \mathrm{CO}_{2}$ of the soil also varied with slope aspect, and soil depth, as well as vegetation types $\times$ slope aspect and vegetation types $\times$ soil depth interactions $(p<0.05$; Tables 3 and 4$)$. Some additional findings were as follows: (i) The soil enzymatic activities and $B R$ in the soil from the east slope were significantly greater than those in the soil from the west slope (e.g., the urease, sucrase, catalase, dehydrogenase, alkaline phosphatase, protease, and cellulase activities and the $B R$ for the east slope were significantly greater than for the west slope by $22.7 \%, 25.0 \%, 4.1 \%, 33.8 \%, 33.1 \%, 18.1 \%, 9.8 \%$, and $9.3 \%$ in July, respectively) ( $p<0.001$; Tables 3 and 4). (ii) The west slope had higher $q \mathrm{CO}_{2}$ than the east slope (Table 3). (iii) The soil enzymatic activities and $B R$ had a significant negative correlation with soil depth (all $r<-0.96, p<0.05$ ), while $q \mathrm{CO}_{2}$ had a positive correlation with soil depth (all $r>0.97, p<0.05$ ). (iv) There were significant interactions between vegetation types and slope aspect, and between vegetation types and soil depth on the soil enzymatic activities, $B R$, and $q \mathrm{CO}_{2}$ (Tables 3 and 4), indicating that the influence of the vegetation types on the soil microbial activities varied with slope aspect and soil depth. 
Table 4. Multivariate ANOVA for the soil enzymatic activities under different types of vegetation in Guanshan grassland.

\begin{tabular}{|c|c|c|c|c|c|c|c|c|}
\hline \multirow[b]{2}{*}{ Source of Variation } & \multirow[b]{2}{*}{ df } & \multicolumn{7}{|c|}{ Mean Squares } \\
\hline & & $\begin{array}{l}\text { Urease } \\
\text { Activity }\end{array}$ & $\begin{array}{l}\text { Sucrase } \\
\text { Activity }\end{array}$ & $\begin{array}{l}\text { Catalase } \\
\text { Activity }\end{array}$ & $\begin{array}{l}\text { Dehydrogenase } \\
\text { Activity }\end{array}$ & $\begin{array}{c}\text { Alkaline } \\
\text { Phosphatase } \\
\text { Activity }\end{array}$ & $\begin{array}{l}\text { Protease } \\
\text { Activity }\end{array}$ & $\begin{array}{l}\text { Cellulase } \\
\text { Activity }\end{array}$ \\
\hline Vegetation types & 2 & $1.18^{* * *}$ & $0.35^{* * *}$ & $0.33 * * *$ & $82.64^{* * * *}$ & $958.66^{* * *}$ & $6151.91^{* * *}$ & $3876.34^{* * *}$ \\
\hline Slope aspect & 1 & $0.26^{* * *}$ & $1.85^{* * *}$ & $0.17^{* * *}$ & $171.36^{* * *}$ & $1393.64^{* * *}$ & $3112.98^{* * *}$ & $1467.33^{* * *}$ \\
\hline Soil depth & 2 & $1.69^{* * *}$ & $2.37^{* * *}$ & $0.20^{* * *}$ & $271.41 * * *$ & $1232.96^{* * *}$ & $12,354.36^{* * *}$ & $10,984.66^{* * *}$ \\
\hline $\begin{array}{c}\text { Vegetation types } \times \\
\text { slope aspect }\end{array}$ & 2 & $0.20 * * *$ & $0.02 * * *$ & $0.00 * * *$ & $2.66^{* * *}$ & $308.95^{* * *}$ & $403.73^{* * *}$ & $359.24^{* * * *}$ \\
\hline $\begin{array}{c}\text { Vegetation types } \times \text { soil } \\
\text { depth }\end{array}$ & 4 & $0.04^{* * *}$ & $0.01 * * *$ & $0.00 * * *$ & $2.29 * * *$ & $40.50 * * *$ & 74.92 ** & $533.99 * * *$ \\
\hline $\begin{array}{c}\text { Slope aspect } \times \text { soil } \\
\text { depth }\end{array}$ & 2 & $0.00 \mathrm{~ns}$ & $0.04^{* * *}$ & $0.01 * * *$ & $0.11 \mathrm{~ns}$ & $17.91 *$ & $48.95 \mathrm{~ns}$ & $13.68 \mathrm{~ns}$ \\
\hline $\begin{array}{c}\text { Vegetation types } \times \\
\text { slope aspect } \times \text { soil } \\
\text { depth }\end{array}$ & 4 & $0.01 \mathrm{~ns}$ & $0.0 \mathrm{~ns}$ & $0.00 *$ & $0.49^{* *}$ & $38.68^{* * *}$ & $34.82 \mathrm{~ns}$ & $24.86 \mathrm{~ns}$ \\
\hline
\end{tabular}

df, degrees of freedom; ${ }^{*} p<0.05 ;{ }^{* *} p<0.01 ;{ }^{* * *} p<0.001 ;$ ns, no significance.

\subsection{Factors Affecting the Soil Microbial Parameters}

An RDA was employed to determine the ordination between the soil physicochemical factors and soil microbial parameters across the degraded vegetation (Figure 8). The RDA ordination plot suggests that all of the soil physicochemical properties could explain $93.7 \%$ of total variation in the soil microbial parameters, with $84.8 \%$ in Axis 1 and $8.9 \%$ in Axis 2 (Figure 8). The smaller angles between the soil physicochemical factors and the axis mean stronger correlations. Therefore, the soil physicochemical properties, particularly $\mathrm{pH}, \mathrm{AN}$, $\mathrm{SOC}, \mathrm{TP}, \mathrm{AP}$, and TN, all played roles in determining the variations in the $\mathrm{Cmic}$, Nmic, and Pmic soil enzymatic activities (i.e., urease, sucrase, catalase, dehydrogenase, alkaline phosphatase, protease, and cellulose), as well as soil BR and $q \mathrm{CO}_{2}$ with $r=0.78,0.74,0.72$, $0.72,0.69$, and 0.65 , respectively $(p<0.05)$ (Figure 8 ). In brief, $\mathrm{pH}, \mathrm{AN}, \mathrm{SOC}, \mathrm{TP}, \mathrm{AP}$, and $\mathrm{TN}$ were the six key factors affecting the soil microbial parameters across the degraded vegetation.

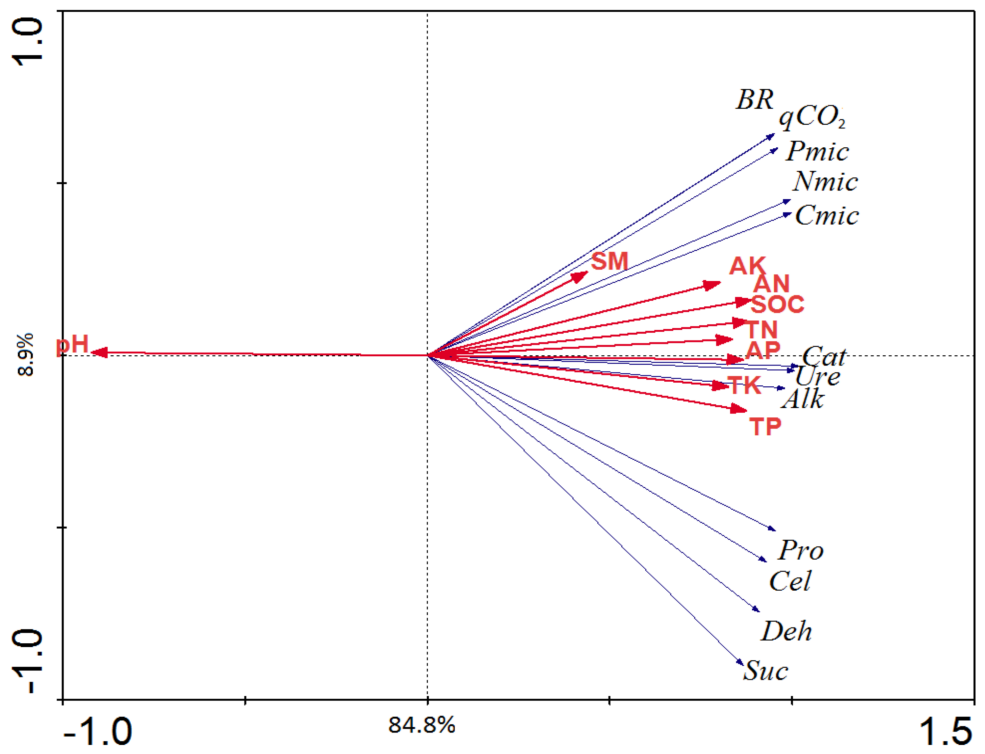

Figure 8. Redundancy analysis (RDA), revealing the relationships between the soil microbial parameters and the physicochemical factors. The soil microbial parameters (Cmic, microbial biomass carbon; Nmic, microbial biomass nitrogen; Pmic, microbial biomass phosphorus; Ure, urease; Suc, sucrase; Cat, catalase; Deh, dehydrogenase; Alk, alkaline phosphatase; Pro, protease; Cel, cellulase; $\mathrm{BR}$, basal respiration; $q \mathrm{CO}_{2}$, metabolic quotient) are illustrated as thin vectors. The soil physicochemical factors (SOC, soil organic carbon; TN, total nitrogen; AN, available nitrogen; TP, total phosphorus; AP, available phosphorus; $\mathrm{TK}$, total potassium; $\mathrm{AK}$, available potassium; $\mathrm{SM}$, soil moisture and $\mathrm{pH}$ ) are illustrated as thick vectors. 


\section{Discussion}

4.1. Impact of the Vegetation Types on the Soil Physicochemical Parameters, Microbial Biomass, Enzymatic Activities, $\mathrm{BR}$, and $q \mathrm{CO}_{2}$

The SOC, TN, AN, TP, AP, TK, and AK declined in the order of FG > SG > HG, meaning that the soil nutrient concentrations were consistent with the levels of vegetation degradation. Similar results were reported in previous studies, in which vegetation degradation resulted in declines in soil nutrient concentrations [27]. Soil nutrient concentrations may be greatly affected by the labile substrate concentration [2]. Vegetation degradation restricts the input and transformation of external material into soil nutrients by limiting the quantity and quality of detritus supplied to soil [3], lowers the soil C fixed level by reducing the above-ground plant species composition and coverage, and accelerates the loss of soil nutrients by changing the soil microclimate (i.e., $\mathrm{pH}$, soil temperature, and moisture conditions) and soil structure. The comprehensive effects of these factors may have resulted in losses of large amounts of $\mathrm{SOC}, \mathrm{TN}, \mathrm{AN}, \mathrm{TP}, \mathrm{AP}, \mathrm{TK}$, and $\mathrm{AK}$ with vegetation degradation. However, soil $\mathrm{pH}$ showed an increasing trend with vegetation degradation, as reported by Muhammad et al. [28], suggesting salinization of the alpine meadow caused by vegetation degradation. Plant root exudates and organic acids produced from changing vegetation may be the main factors causing a decline in the soil acidity with vegetation degradation [13].

The soil microbial biomass, enzymatic activities, and BR decreased in the order of FG $>\mathrm{SG}>\mathrm{HG}$ in the soils from both the east and west slopes of Guanshan grassland, similar to previous studies in which vegetation variations affected the soil microbial parameters [9,29]. For example, Chandregowda et al. [30] found that shrubs had higher microbial biomass and BR compared to grasslands in a tropical semi-arid grazing ecosystem. Tiwari et al. [31] also reported that the soil microbial biomass declined from natural forests to savannas and agricultural land in dry tropical upland soil. The soil microbial biomass often accounts for $1-5 \%$ of soil organic matter [32], representing an important pool of available nutrients. Therefore, the gradual declines in $\mathrm{Cmic}$, Nmic, and Pmic with vegetation degradation indicate that the soil labile $\mathrm{C}, \mathrm{N}$, and $\mathrm{P}$ pools also declined $[9,32]$. The activities of $\mathrm{C}$-cycling enzymes (sucrase and cellulase), N-cycling enzymes (urease and protease), and P-cycling enzyme (alkaline phosphatase) declined in the order of FG > SG > HG in Guanshan grassland, implying that soil C, N, and P turnover and cycling declined with vegetation degradation in this ecosystem [33]. Soil catalase and dehydrogenase, as intracellular enzymes, are primarily caused by soil microbes and are therefore indicators of active microbes, and gradually decreased in the order of FG > SG > HG, suggesting a decline in the soil microbial activities following vegetation degradation. The decline in soil microbial activities further limits the rate of soil organic matter mineralization and decreases $C$ use efficiency, which was proven by the declined $\mathrm{BR}$ and enhanced $q \mathrm{CO}_{2}$ following vegetation degradation (Figures 6 and 7). Therefore, the reductions in the soil microbial biomass, enzymatic activities, and BR all imply that the soil C, N, and P pools and transformations declined due to vegetation degradation in this grassland ecosystem.

Several mechanisms could likely explain these reduced soil microbial biomass, enzymatic activities, and $\mathrm{BR}$ and increased $q \mathrm{CO}_{2}$ with vegetation degradation. First, the higher frequency trampling from thousands of tourists, the overgrazing of horses for tourism project-based horse riding, the numerous cattle as an important source of local foods in HG, and the relatively convenient traffic - being closer to the S212 road and at lower altitude compared to FG and SG-have all led to the declines in species diversity and above-ground biomass and coverage of vegetation in the study areas [5]. Second, these vegetation variations may have further changed the soil physicochemical characteristics by limiting both the quantity and quality of residues and by disturbing the nutrient cycling and changing soil microhabitat (i.e., unstable temperature, increased soil bulk and $\mathrm{pH}$, and lower oxygen content and moisture), thus restraining the amount and activities of the soil microorganism. As we found, the soil physicochemical characteristics had significant correlations with the soil microbial parameters (Figure 8). Similar conclusions were found 
by Muhammad et al. [28] and Yuan et al. [3], suggesting that the nutrient concentrations and $\mathrm{pH}$ were some of the main reasons for the soil microbial biomass and activity changes.

4.2. Impact of the Slope Aspect and Soil Depth on the Soil Microbial Biomass, Enzymatic Activities, $\mathrm{BR}$, and $q \mathrm{CO}_{2}$

Our results showed that the east slope, with more solar radiation, had significantly higher soil microbial biomass, enzymatic activities, and BR than the west slope, whereas $q \mathrm{CO}_{2}$ had an opposite trend. Similar conclusions have been reported, in which slope aspect can influence the $\mathrm{Cmic}$, Nmic, Pmic, enzymatic activities (i.e., urease, catalase, and protease), $\mathrm{BR}$, and $q \mathrm{CO}_{2}[15,34-37]$. In comparison to the west slope, the east slope, with a relatively flat slope, had higher soil temperature due to stronger solar radiation, better moisture conditions, lower $\mathrm{pH}$, and greater soil nutrient content (i.e., $\mathrm{C}, \mathrm{N}$, and $\mathrm{P}$ ), as shown in Table 2, which improved the microbial growth and reproduction and further facilitated the plant growth and the decomposition rate of the plant residues into the soil organic matter $[35,38]$. Previous studies have also reported that lower soil $\mathrm{pH}$, better temperature and moisture conditions, and greater soil nutrient content can promote microbial growth and reproduction, and further promote plant growth [35]. Plant growth, in turn, increased the soil microbial biomass, enzyme activities, and BR and reduced the $q \mathrm{CO}_{2}$.

The higher Cmic and C-cycling enzymes (sucrase and cellulase) in the soil from the east slope suggest that it had greater available soil $\mathrm{C}$ pools and more efficient utilization of soil $C$ for plant growth and tissue maintenance compared to the west slope $[15,35]$. Meanwhile, the higher Nmic, Pmic, N-cycling enzymes (urease and protease), and Pcycling enzyme (alkaline phosphatase) in the soil from the east compared to the west slope suggest that it had greater available soil $\mathrm{N}$ and $\mathrm{P}$ pools and more efficient $\mathrm{N}$ and $\mathrm{P}$ use for plants $[39,40]$. The lower $q \mathrm{CO}_{2}$ in the soil from the east slope than the west slope may indicate a high carbon use efficiency [41]. The high levels of BR in the soil from the east slope reflect that the soil conditions were favorable for microbial growth [39], suggesting a better soil quality. The obvious interaction between vegetation types and slope aspect in terms of the soil microbial parameters suggests that the negative effect of vegetation degradation on soil quality is more serious for the west slope than the east slope.

Soil microbial biomass, enzymatic activities, and BR were negatively correlated with soil depth, whereas $q \mathrm{CO}_{2}$ was positively correlated with soil depth, as previously observed by Huang et al. [39] and Wang et al. [42]. These results indicate that the available soil nutrient pools and nutrient use efficiency, including $\mathrm{C}, \mathrm{N}$, and $\mathrm{P}$, decreased with increasing soil depth across vegetation degradation. A higher soil nutrient level (e.g., SOC, TN, AN, $\mathrm{TP}, \mathrm{AP}, \mathrm{TK}$, and $\mathrm{AK}$ ), as found by our study, possibly due to the great input from abundant plant species or plant litters [43] and suitable microenvironment (i.e., high oxygen content, good soil moisture and temperature conditions) in the surface, improved the soil microbial growth and reproduction, and resulted in higher soil microbial biomass, enzymatic activities, and $\mathrm{BR}$ and in a lower $q \mathrm{CO}_{2}$ compared to the deeper soils. Furthermore, our study also found that vegetation types and soil depth have obvious interactions on these studied microbial indexes, as suggested by previous studies [42]. These results may indicate that soil degradation will occur not only in surface soil, but also in deep soil, as the continuous vegetation degradation in Guanshan grassland.

\section{Conclusions}

Our study indicated that vegetation degradation suppressed the soil microbial biomass and activities in Guanshan grassland. Declines in Cmic, Nmic, Pmic, BR, and the activities of soil urease, sucrase, catalase, dehydrogenase, alkaline phosphatase, protease, and cellulase, as well as raised $q \mathrm{CO}_{2}$ caused by vegetation degradation, were found in the soil from the east and west slopes of Guanshan grassland in both April and July 2017, implying that the soil $\mathrm{C}, \mathrm{N}$, and $\mathrm{P}$ nutrient pools and utilization declined following vegetation degradation. The declines in $\mathrm{pH}, \mathrm{AN}, \mathrm{SOC}, \mathrm{TP}, \mathrm{AP}$, and $\mathrm{TN}$ were key factors affecting the soil microbial biomass and activities across vegetation degradation. In addition, the soil microbial parameters obviously varied with slope aspects and soil depths. The east slope 
had greater soil microbial biomass, enzyme activities, and BR and a lower $q \mathrm{CO}_{2}$ than the west slope due to the relatively strong sunlight and flat slope. Hence, vegetation degradation led to a declined soil quality, indicting the degradation of the Guanshan grassland ecosystem.

Author Contributions: Conceptualization, Y.L. and H.Y.; methodology, Y.L.; software, Y.Z.; validation, Y.L., H.Y. and Z.C.; formal analysis, Y.L. and Z.X.; investigation, Y.L., H.Y. and Z.C.; resources, H.Y.; data curation, Y.L. and Y.Z.; writing-original draft preparation, Y.L.; writing-review and editing, Y.L. and Z.X.; visualization, Y.L. and Z.X.; supervision, Z.X. and Y.Z.; project administration, Y.L. and H.Y.; funding acquisition, Y.L. All authors have read and agreed to the published version of the manuscript.

Funding: This research was subsidized by the National Natural Science Foundation of China (approval numbers 41761057 and 31860146), the Fund of Longyuan Talent Innovation Team Project, and the Flying Scholar Plan, Gansu Province.

Data Availability Statement: Data is contained within the article.

Conflicts of Interest: The authors declare no conflict of interest.

\section{References}

1. Ma, W.J.; Li, J.; Jimoh, S.O.; Zhang, Y.J.; Guo, F.H.; Ding, Y.; Li, X.L.; Hou, X.Y. Stoichiometric ratios support plant adaption to grazing moderated by soil nutrients and root enzymes. PeerJ 2019, 7, 15. [CrossRef] [PubMed]

2. Dong, C.C.; Wang, W.; Liu, H.Y.; Xu, X.T.; Zeng, H. Temperate grassland shifted from nitrogen to phosphorus limitation induced by degradation and nitrogen deposition: Evidence from soil extracellular enzyme stoichiometry. Ecol. Indic. 2019, 101, 453-464. [CrossRef]

3. Yuan, Z.Q.; Jiang, X.J.; Liu, G.J.; Jin, H.J.; Chen, J.; Wu, Q.B. Responses of soil organic carbon and nutrient stocks to human-induced grassland degradation in a Tibetan alpine meadow. Catena 2019, 178, 40-48. [CrossRef]

4. Zhou, W.; Gang, C.; Zhou, L.; Chen, Y.; Li, J.; Ju, W.; Odeh, I. Dynamic of grassland vegetation degradation and its quantitative assessment in the northwest China. Acta. Oecol. 2014, 55, 86-96. [CrossRef]

5. Hu, Y.B.; Guo, T.; Chen, J. Research on characteristics of vegetation community structure at different altitudes in Guanshan grasslands. Pratacult. Sci. 2013, 30, 190-195. (In Chinese)

6. Ren, Z.Y.; Song, B.P.; Zhang, H. Ecological environmental protection and construction in the development of Guanshan Grassland Tourism Scenic Area. J. Dese. Rese. 2000, 1, 87-90. (In Chinese)

7. Dong, S.K.; Wen, L.; Yi, Y.Y.; Wang, X.X.; Zhu, L.; Li, X.Y. Soil-quality effects of grassland degradation and restoration on the Qinghai-Tibetan plateau. Soil Sci. Soc. Am. J. 2012, 76, 2256-2264. [CrossRef]

8. Liu, S.B.; Zamanian, K.; Schleuss, P.M.; Zarebanadkouki, M.; Kuzyakov, Y. Degradation of Tibetan grasslands: Consequences for carbon and nutrient cycles. Agric. Ecosyst. Environ. 2018, 252, 93-104. [CrossRef]

9. Feng, C.; Ma, Y.H.; Jin, X.; Wang, Z.; Ma, Y.; Fu, S.L.; Chen, H.Y.H. Soil enzyme activities increase following restoration of degraded subtropical forests. Geoderma 2019, 351, 180-187. [CrossRef]

10. Bargali, K.; Manral, V.; Padalia, K.; Bargali, S.S.; Upadhyay, V.P. Effect of vegetation type and season on microbial biomass carbon in Central Himalayan forest soils, India. Catena 2018, 171, 125-135. [CrossRef]

11. Kuscu, I.S.K. Changing of soil properties and urease-catalase enzyme activity depending on plant type and shading. Environ. Monit. Assess. 2019, 191, 178. [CrossRef] [PubMed]

12. Anderson, T.H.; Domsch, K.H. Determination of ecophysiological maintenance carbon requirements of soil microorganisms in a dormant stare. Biol. Fert. Soils 1985, 1, 81-89. [CrossRef]

13. Zhao, C.; Long, J.; Liao, H.K.; Zheng, C.L.; Li, J.; Liu, L.F.; Zhang, M.J. Dynamics of soil microbial communities following vegetation succession in a karst mountain ecosystem, southwest China. Sci. Rep. 2019, 9, 2160. [CrossRef]

14. Ramirez, K.S.; Craine, J.M.; Fierer, N. Consistent effects of nitrogen amendments on soil microbial communities and processes across biomes. Glob. Chang. Biol. 2012, 18, 1918-1927. [CrossRef]

15. Pan, F.J.; Zhang, W.; Liang, Y.M.; Liu, S.J.; Wang, K.L. Increased associated effects of topography and litter and soil nutrients on soil enzyme activities and microbial biomass along vegetation successions in karst ecosystem, southwestern China. Environ. Sci. Pollut. Res. 2018, 25, 16979-16990. [CrossRef]

16. Rasouli-Sadaghiani, M.H.; Barin, M.; Siavash, S.M.; Damalas, C.A.; Ghodrat, K. Soil quality of an Iranian forest ecosystem after conversion to various types of land use. Environ. Monit. Assess. 2018, 190, 447. [CrossRef]

17. Lungmuana; Singh, S.B.; Choudhury, B.U.; Vanthawmliana; Saha, S.; Hnamte, V. Transforming jhum to plantations: Effect on soil microbiological and biochemical properties in the foot hills of North Eastern Himalayas, India. Catena 2019, 177, 84-91.

18. Wu, J.; Joergensen, R.G.; Pommerening, B.; Chaussod, R.; Brookes, P.C. Measurement of soil microbial biomass C by fumigationextraction-an automated procedure. Soil Biol. Biochem. 1990, 22, 1167-1169. [CrossRef] 
19. Lu, R.K. Analytical Methods for Soil and Agricultural Chemistry; China Agricultural Science and Technology Press: Beijing, China, 1999; pp. 107-150. (in Chinese)

20. Bremner, J.M. Nitrogen-Total. In Methods of Soil Analysis. Part 3. Soil Science Society of America; Sparks, D.L., Ed.; American Society of Agronomy: Madison, WI, USA, 1996; pp. 1085-1086.

21. Olsen, S.R.; Cole, C.V.; Watanabe, F.S.; Dean, N.C. Estimation of Available Phosphous in Soil by Extraction with Sodium Bicorbonate; United States Department of Agriculture: Washington, DC, USA, 1954; p. 939.

22. Bao, S.D. Agro-Chemical Analysis of Soil; China Agriculture Press: Beijing, China, 2000; pp. 22-108. (In Chinese)

23. Brookes, P.C.; Landman, A.; Pruden, G.; Jenkinson, D.S. Chloroform fumigation and the release of soil organic nitrogen: A rapid direct extraction method to measure microbial biomass nitrogen in soils. Soil Biol. Biochem. 1985, 17, 837-842. [CrossRef]

24. Brookes, P.C.; Powlson, D.S.; Jenkinson, D.S. Measurement of microbial biomass phosphorus in soil. Soil Biol. Biochem. 1982, 14, 319-329. [CrossRef]

25. Vance, E.D.; Brookes, P.C.; Jenkinson, D.S. An extraction method for measuring soil microbial biomass C. Soil Biol. Biochem. 1987, 19, 703-707. [CrossRef]

26. Liu, Y.M.; Xing, Z.S.; Yang, H.Y. Effect of biological soil crusts on microbial activity in soils of the Tengger Desert (China). J. Arid Environ. 2017, 144, 201-211. [CrossRef]

27. Cui, Y.X.; Fang, L.C.; Guo, X.B.; Wang, X.; Wang, Y.Q.; Zhang, Y.J.; Zhang, X.C. Responses of soil bacterial communities, enzyme activities, and nutrients to agricultural-to-natural ecosystem conversion in the Loess Plateau, China. J. Soils Sediments 2019, 19, 1427-1440. [CrossRef]

28. Muhammad, N.; Dai, Z.M.; Xiao, K.C.; Meng, J.; Brookes, P.C.; Liu, X.M.; Wang, H.Z.; Wu, J.J.; Xu, J.M. Changes in microbial community structure due to biochars generated from different feedstocks and their relationships with soil chemical properties. Geoderma 2014, 226-227, 270-278. [CrossRef]

29. Balota, E.L.; Yada, I.F.; Amaral, H.; Nakatani, A.S.; Dick, R.P.; Coyne, M.S. Long-term land use influences soil microbial biomass P and S, phosphatase and arylsulfatase activities, and S mineralization in a Brazilian Oxisol. Land Degrad. Dev. 2014, 25, 397-406. [CrossRef]

30. Chandregowda, H.; Murthy, K.; Bagchi, S. Woody shrubs increase soil microbial functions and multifunctionality in a tropical semi-arid grazing ecosystem. J. Arid Environ. 2018, 155, 65-72. [CrossRef]

31. Tiwari, S.; Singh, C.; Boudh, S.; Rai, P.K.; Gupta, V.K.; Singh, J.S. Land use change: A key ecological disturbance declines soil microbial biomass in dry tropical uplands. J. Environ. Manag. 2019, 242, 1-10. [CrossRef]

32. Sun, B.; Hallett, P.D.; Caul, S.; Daniell, T.J.; Hopkins, D.W. Distribution of soil carbon and microbial biomass in arable soils under different tillage regimes. Plant Soil 2010, 338, 17-25. [CrossRef]

33. Xiao, L.; Bi, Y.L.; Du, S.Z.; Wang, Y.; Guo, C. Effects of re-vegetation type and arbuscular mycorrhizal fungal inoculation on soil enzyme activities and microbial biomass in coal mining subsidence areas of Northern China. Catena 2019, 177, 202-209. [CrossRef]

34. Liu, W.X.; Xu, W.H.; Hong, J.P.; Wan, S.Q. Interannual variability of soil microbial biomass and respiration in responses to topography, annual burning and $\mathrm{N}$ addition in a semiarid temperate steppe. Geoderma 2010, 158, 259-267. [CrossRef]

35. Tian, Y.W.; Qiao, D.; Xu, S.J.; Wang, N. Effects of tree species and topography on soil and microbial biomass stoichiometry in Funiu Mountain, China. BMC Ecol. 2020, 20, 67. [CrossRef]

36. Johnson, D.; Leake, J.R.; Read, D.J. Liming and nitrogen fertilization affects phosphatase activities, microbial biomass and mycorrhizal colonisation in upland grassland. Plant Soil 2005, 271, 157-164. [CrossRef]

37. Zhang, W.J.; Li, R.R.; Ai, X.Y.; Chen, J.; Xu, W.N.; Li, W.; Ai, Y.W. Enzyme activity and microbial biomass availability in artificial soils on rock-cut slopes restored with outside soil spray seeding (OSSS): Influence of topography and season. J. Environ. Manag. 2018, 211, 287-295. [CrossRef]

38. Ghee, C.; Neilson, R.; Hallet, P.D.; Robinson, D.; Paterson, E. Priming of soil organic matter mineralisation is intrinsically insensitive to temperature. Soil Biol. Biochem. 2013, 66, 20-28. [CrossRef]

39. Huang, Y.M.; Liu, D.; An, S.S. Effects of slope aspect on soil nitrogen and microbial properties in the Chinese Loess region. Catena 2015, 125, 135-145. [CrossRef]

40. Joergensen, R.G.; Kubler, H.; Meyer, B.; Wolters, V. Microbial biomass phosphorus in soils of beech (fagus-sylvatica l) forests. Biol. Fert. Soils 1995, 19, 215-219.

41. Wardle, D.A.; Ghani, A. A critique of the microbial metabolic quotient (qCO2) as a bio-indicator of disturbance and ecosystem development. Soil Biol. Biochem. 1995, 27, 1601-1610. [CrossRef]

42. Wang, H.Y.; Wu, J.Q.; Li, G.; Yan, L.J. Changes in soil carbon fractions and enzyme activities under different vegetation types of the northern Loess Plateau. Ecol. Evol. 2020, 10, 12211-12223. [CrossRef] [PubMed]

43. Oduor, C.O.; Karanja, N.K.; Onwonga, R.N.; Mureithi, S.M.; Pelster, D.; Nyberg, G. Enhancing soil organic carbon, particulate organic carbon and microbial biomass in semi-arid rangeland using pasture enclosures. BMC Ecol. 2018, 18, 45. [CrossRef] 